ASLI QoL 2021

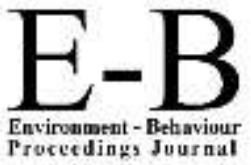

\title{
AQoL2021LangkawiIsland
}

https://www.amerabra.org; https://fspu.uitm.edu.my/cebs; https://www.emasemasresources.com/ $5^{\text {th }}$ ABRA International Conference on Quality of Life Holiday Villa Langkawi, Langkawi Island, Malaysia, 15-16 Dec 2021

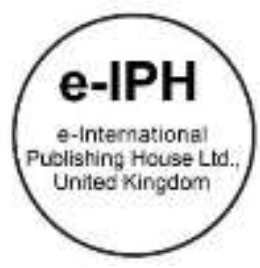

\section{Public Awareness of British Pillboxes in Bachok, Kelantan from a Heritage Tourism Perspective}

\author{
Nur Athmar Hashim ${ }^{1}$, Siti Aisyah Muhammad 2, Tengku Fauzan Tengku Anuar ${ }^{1}$, \\ Iwan Zahar ${ }^{3}$, Nur Farhana Shuhaimi ${ }^{1}$ \\ ${ }^{1}$ Faculty of Creative Technology and Heritage, ${ }^{2}$ Faculty of Architecture and Ekistics, \\ Universiti Malaysia Kelantan, Malaysia \\ ${ }^{3}$ Faculty Industrial and Design, University Esa Unggul, Indonesia
}

athmar.h@umk.edu.my , aisyah@umk.edu.my , tengkufauzan@umk.edu.my ,iwan.zahar@esaunggul.ac.id, hannashuhaimi969@gmail.com. Tel: 01155023215

\begin{abstract}
The British pillboxes built in Kelantan in 1941 during World War II, although damaged, continue to attract tourists. However, they have considerably less impact on residents, with the exception of war veterans, and there are plans to relocate the pillboxes in Bachok. The present study uses a range of methods to analyze the structures and to evaluate community awareness of them: field observation and setting coordinates for all pillboxes, taking photographs to consolidate data, and administering a questionnaire to 100 respondents. The results show that these monuments can be an economic resource and can help to raise awareness of historical value in relation to the formation of Malaysia.
\end{abstract}

Keywords: British Pillbox, Bachok coast, Heritage tourism, Kelantan.

eISSN: 2398-4287C 2021. The Authors. Published for AMER ABRA cE-Bs by e-International Publishing House, Ltd., UK. This is an open access article under the CC BYNCND license (http://creativecommons.org/licenses/by-nc-nd/4.0/). Peer-review under responsibility of AMER (Association of Malaysian Environment-Behaviour Researchers), ABRA (Association of Behavioural Researchers on Asians/Africans/Arabians) and cE-Bs (Centre for Environment-Behaviour Studies), Faculty of Architecture, Planning \& Surveying, Universiti Teknologi MARA, Malaysia.

DOI: https://doi.org/10.21834/ebpj.v6i18.3087

\subsection{Introduction}

Japanese military forces occupied Malaysia in World War II, attacking Kelantan on December 8 and Singapore on December 10, 1941, and fully occupying the whole of Malaysia on 15 February 1941 (Jeffry Heys, 2008). The speed of the invasion proved that the British were not well prepared for the unpredictable forms of attack used by the Japanese forces, despite the large number of pillboxes that had been built for defense purposes.

In Kelantan, the majority of pillboxes were located near the coast, in Bachok (Figure 1), although some were located in Kota Bharu, Machang, Tumpat, and Kuala Krai. They were built to enable British troops to defend the area against invasion. They are evidence of Malaysian involvement in World War II, and therefore monuments of great historical significance. The events of the war were horrific and left their scars on the people of Malaysia. Nevertheless, today's younger generations are less interested in history, and their awareness and acknowledgment of the events is relatively low.

eISSN: 2398-4287@ 2021. The Authors. Published for AMER ABRA cE-Bs by e-International Publishing House, Ltd., UK. This is an open access article under the CC BYNCND license (http://creativecommons.org/licenses/by-nc-nd/4.0/). Peer-review under responsibility of AMER (Association of Malaysian Environment-Behaviour Researchers), ABRA (Association of Behavioural Researchers on Asians/Africans/Arabians) and cE-Bs (Centre for Environment-Behaviour Studies), Faculty of Architecture, Planning \& Surveying, Universiti Teknologi MARA, Malaysia.

DOI: https://doi.org/10.21834/ebpj.v6i18.3087 


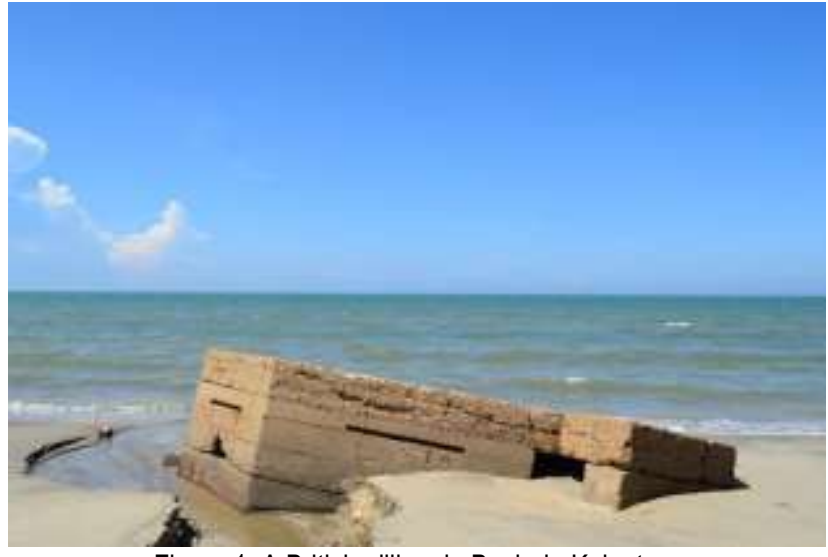

Figure 1: A British pillbox in Bachok, Kelantan. Source: Field study (2021).

According to the National Heritage Act 2005 (Act 645), monuments are architectural and sculptural works or structures of an archeological type with universal values that relate to heritage history, art, or science (AW Kebangsaan, 2006). A pillbox is a defensive structure that enables troops to resist attack by superior forces. The standard dictionary defines a pillbox as a small round concrete emplacement for machine-guns and anti-tank guns. Pillboxes can also be characterized as machine-gun post wells protected with concrete.

Many of the pillboxes built in Malaysia remained in place after the war. This study focuses on the pillboxes in Kelantan and on public awareness of them as monuments with heritage value for society. The objectives of the study are to locate precisely the remaining British pillboxes in Bachok, Kelantan and to measure public awareness of these structures and their significance.

\subsection{Literature Review}

The events of World War II in Malaysia constitute a history that the community, and especially its veterans, cannot forget. The war contributed significantly to the formation of Malaysia and its independence; in its aftermath, the country became stronger and founded the parties that worked to eliminate colonialism. Rich in resources for export, such as rubber and tin, Malaysia had long been a target for colonial countries to conquer (Jeffrey Hays, 2008).

The Japanese military forces that invaded Malaysia in World War II were known as the Takumi detachment, as they were led by MajorGeneral Hiroshi Takumi. The invasion force left the port of Samah, Hainan Island, on December 4 and arrived in Thailand on December 7, 1941. It included three large transportation ships: MS Awagisan Maru (9,794 tons), MS Ayatosan Maru (9,800 tons), and MS Sakura Maru (7,100 tons). There were also light cruisers, and a destroyer squad to escort them. Five minutes after these vessels cast anchor approximately a mile and a half from Sabak beach, British defense troops stationed there (Figure 2) received reports of their arrival and opened fire. Following this first skirmish, British troops were bombed by a Japanese military ship (Nik Mohamed, 1988).

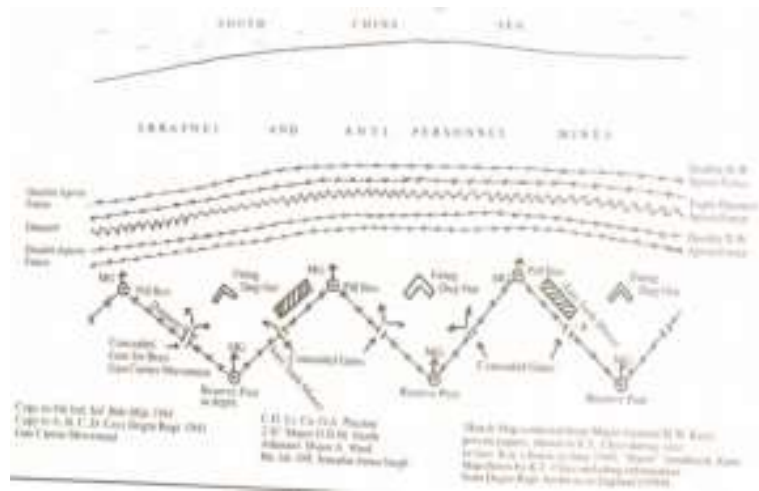

Figure 2: The Montgomery Camp of the British forces. Source: HL Wrigglesworth (1991).

The British defense in Kelantan consisted of the 8th Indian Infantry Brigade under the command of Brigadier Berthold Wells Key. They had been assigned to protect and defend the Kota Bharu airfield (Figure 3). These troops were allocated between two sectors. In the right sector, which included Semerak, Malawi, and Bachok beaches, the pillboxes built for defense were positioned approximately $1 \mathrm{~km}$ apart from each other. The left sector consisted of Kemasin beach from Kuala Kemasin to Sungai Pengkalan Datu, Sabak beach from Sungai Pengkalan Datu, and Badang beach from Kuala Pak Àmat to the Kelantan river. Pillboxes were also built there, some of which remain (HL Wrigglesworth, 1991). 


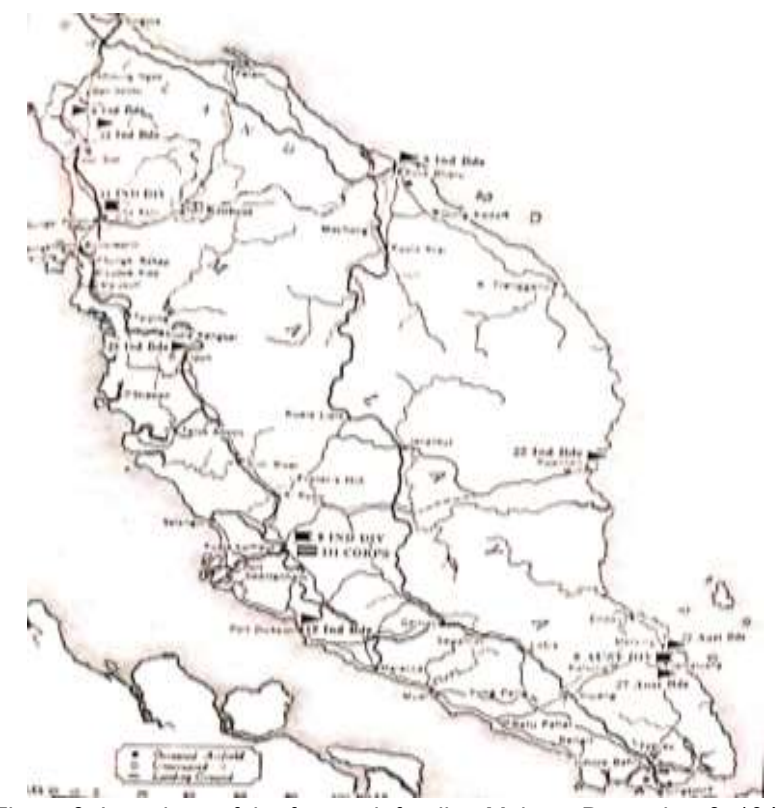

Figure 3: Locations of the forces defending Malaya, December 8, 1941 Source: HL Wrigglesworth (1991).

Most of the 30 British pillboxes that remain in Kelantan were built on the coast to defend it against naval attack, and they have the potential to generate income as part of the tourism sector. Built by teams of British and Punjabi soldiers (DJ Dolasoh, 2015), they are roughly square in shape and feature small openings through which soldiers could counter-attack with gunfire. Entry and exit was via a doorway at the back of the structure. The pillboxes are typically $6 \mathrm{~m}$ high by $6 \mathrm{~m}$ wide and located very near the beach. However, most of them have suffered significant damage in the form of sedimentation and corrosion, and have sunk into the sand and the sea.

During World War II, pillboxes were important in Malaysia, as they had been built to defend the British logistics area and to slow any attack by the Japanese military. The pillboxes in Kelantan were constructed in 1940, immediately after the British received intelligence that Japanese forces would attack from Thailand with the aim of occupying Malaysia. The attack took place a month later (Farhana Shuhaimi, 2020).

\subsection{Methodology}

This study used both qualitative methods (based on observation, discussion, and documentation; Patton, 1990) and quantitative methods (based on quantities and items that can be counted) to collect data for analysis. First, a review of the literature was used to find keywords in relation to the locations of British pillboxes and to provide initial descriptions of the relevant areas (Figure 4). GPS (global positioning system) technology was used to record and establish the precise coordinates of the British pillboxes in Bachok, Kelantan. To ensure accurate data, the coordinates were set using four angles on each pillbox.

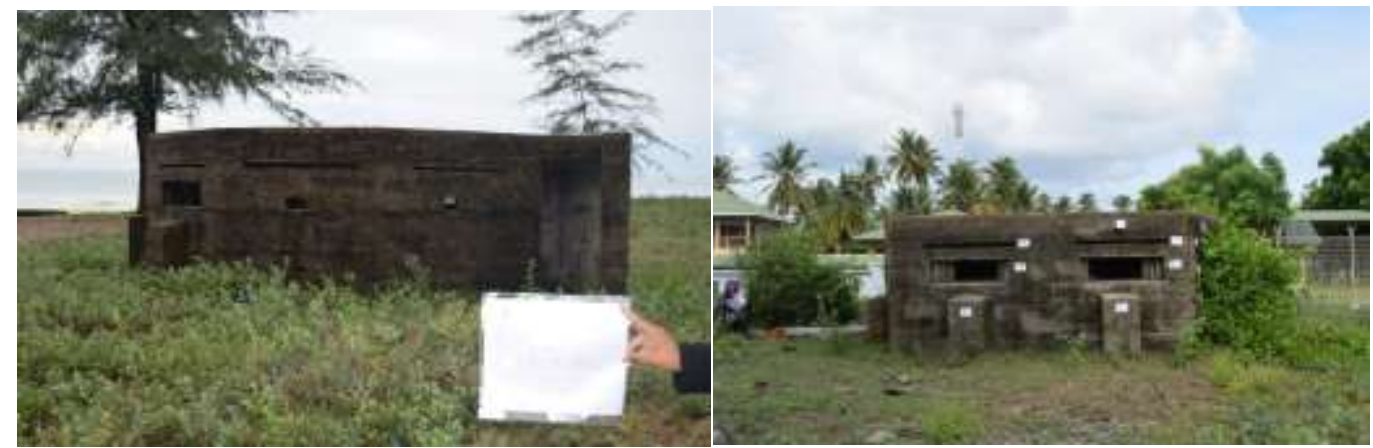

Figure 4: A British pillbox located in Bachok, Kelantan. Source: Field study (2020).

Next, observation and photographic methods were used to focus on the pillboxes as structures. Of the 11 pillboxes that remain in Bachok, only six are still in good condition. The methods therefore included taking detailed measurements of the structures and compiling photographic evidence to support further analysis (Figure 5). This process revealed that all of the pillboxes were located near the coast, and that some of the structures were surrounded by villages. Moreover, some of the pillboxes were badly damaged and at risk of further deterioration. 


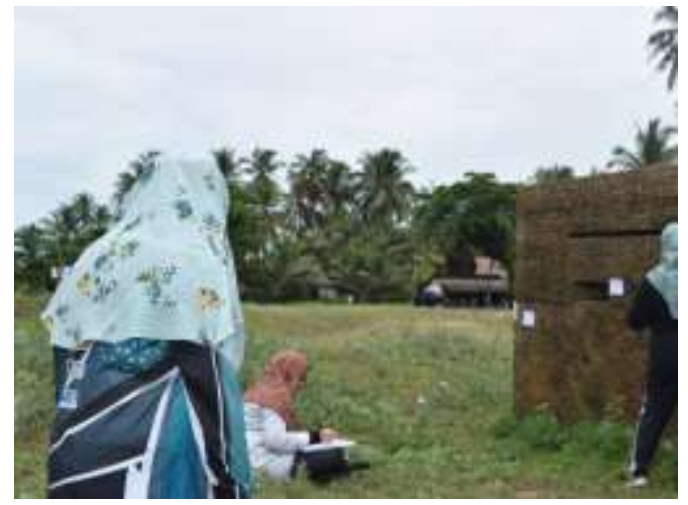

Figure 5: The process of measuring British pillboxes in Bachok, Kelantan Source: Field study (2020).

The quantitative element of the study involved the distribution of an online questionnaire to 100 respondents using Google Forms (Figure 6). The questions were designed to elicit respondents' awareness and knowledge of the British pillboxes in Bachok, Kelantan in order to assess the extent of public understanding. The respondents, who came from a range of occupations, were all resident in Bachok and aged between 20 and 50 .

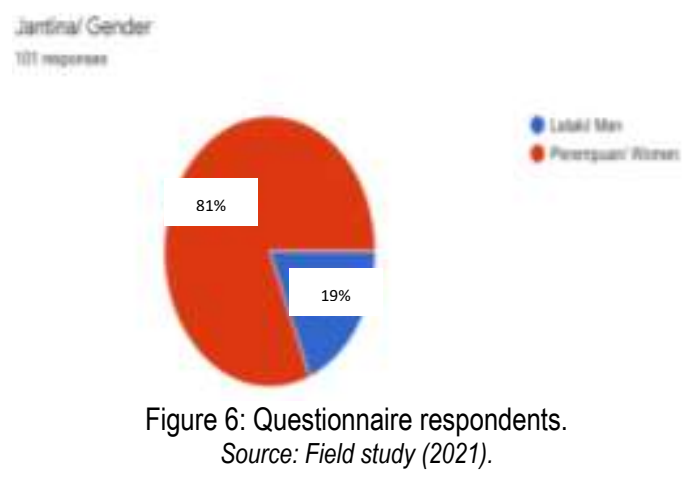

\subsection{Result and Discussion}

\subsection{Location of Pillbox in Bachok, Kelantan.}

A total of 11 pillbox monuments remains in Bachok, Kelantan (Figure 7, Table 1). Some of them are dilapidated, but others are in reasonably good condition. Since some pillboxes are located near houses where local villagers live, it is challenging to conserve them using familiar methods. There has also been some vandalism; teenagers, often unaware of the historical significance of the monuments, tend to congregate around them. Most of the pillboxes in Bachok are closed to the beach, in line with their strategic purpose of preventing enemy attack by sea. The British army expected the Japanese military to attempt to capture the state of Kelantan from three directions: by air, sea, and land. Table 1 lists the coordinates of the remaining pillboxes in Bachok. This research adopting the theory of restoration which considered the adaptation of architectural heritage that must be conserved.

Table 1: Coordinates of the remaining British pillboxes in Bachok, Kelantan.

\begin{tabular}{|c|c|}
\hline Location & Coordinate \\
\hline Kampung Ger & $\left(6^{\circ} 00^{\circ} 00.4^{\circ} \mathrm{N}, 102^{\circ} 22^{\prime} 55.2^{\circ} \mathrm{E}\right)$ \\
\hline Kampung Tok Burung & $\left(6^{\circ} 04^{\prime} 33.7^{\circ} \mathrm{N}, 102^{\circ} 23^{\circ} 45.5^{\circ} \mathrm{E}\right)$ \\
\hline Kampung Sungai Rekang & $\left(6^{\circ} 00^{\prime} 31.7^{\circ} \mathrm{N}, 102^{\circ} 25^{\circ} 31.5^{\circ} \mathrm{E}\right)$ \\
\hline Kampung Anak Rhu & $\left(6^{\circ} 00^{\circ} 58.1^{1} \mathrm{~N}, 102^{\circ} 24^{\circ} 45.2^{\circ} \mathrm{E}\right)$ \\
\hline Pantai Tok Abah & $\left(6^{\circ} 02^{\prime} 32.1^{1} \mathrm{~N}, 102^{\circ} 24^{\circ} 30.6^{\circ} \mathrm{E}\right)$ \\
\hline Kampung Pantai Baru & $\left(6^{\circ} 00^{\circ} 41.9^{\circ} \mathrm{N}, 102^{\circ} 24^{\circ} 56.5^{\circ} \mathrm{E}\right)$ \\
\hline Kampung Pengkalan Chap & $\left(5^{\circ} 51^{\circ} 09.9^{\circ} \mathrm{N}, 102^{\circ} 31^{\circ} 07.5^{\circ} \mathrm{E}\right)$ \\
\hline Kampung Pulau Belongan & $\left(6^{\circ} 03^{\prime} 29.2^{\circ} \mathrm{N}, 102^{\circ} 23^{\prime} 54.7^{\circ} \mathrm{E}\right)$ \\
\hline Kampung Kubang Kawah & $\left(6^{\circ} 05^{\circ} 10.4^{\circ} \mathrm{N}, 102^{\circ} 23^{\circ} 30.0^{\circ} \mathrm{E}\right)$ \\
\hline
\end{tabular}




\begin{tabular}{ll}
\hline Kampung Kubang Golok & $\left(6^{\circ} 05^{\prime} 41.5^{\circ} \mathrm{N}, 102^{\circ} 23^{\prime} 16.3^{\circ} \mathrm{E}\right)$ \\
Kampung Merabang & $\left(6^{\circ} 06^{\prime} 19.6^{\circ} \mathrm{N}, 102^{\circ} 22^{\circ} 59.3^{\circ} \mathrm{E}\right)$
\end{tabular}

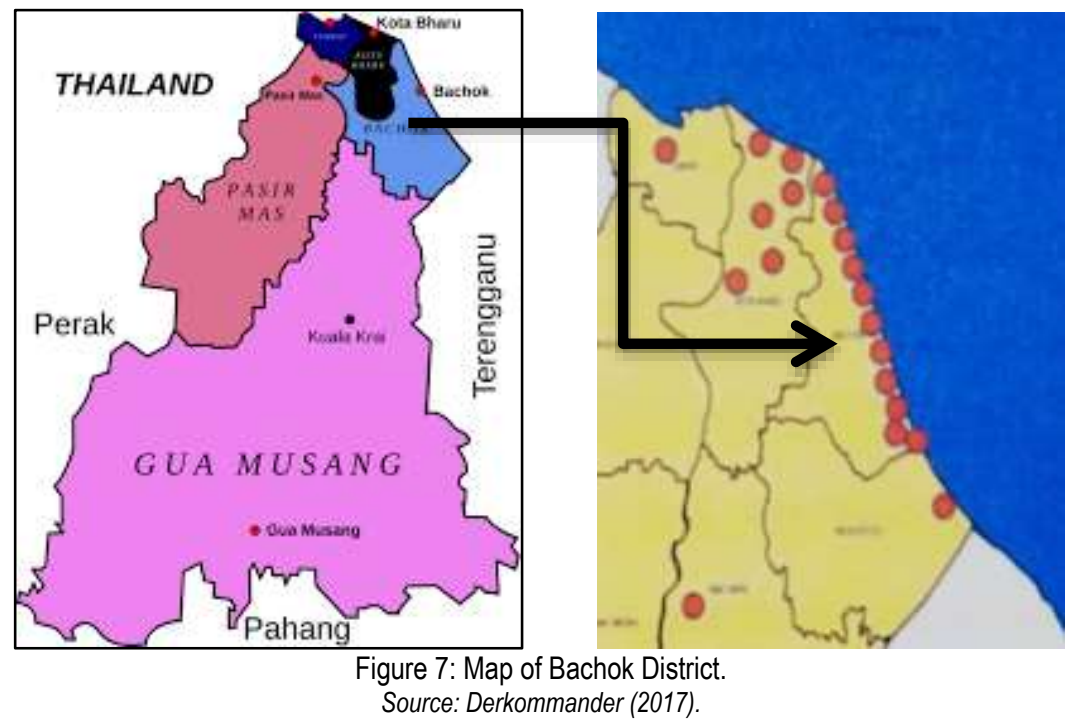

\subsection{Structure of Pillbox in Bachok, Kelantan.}

\subsubsection{Kg Ger}

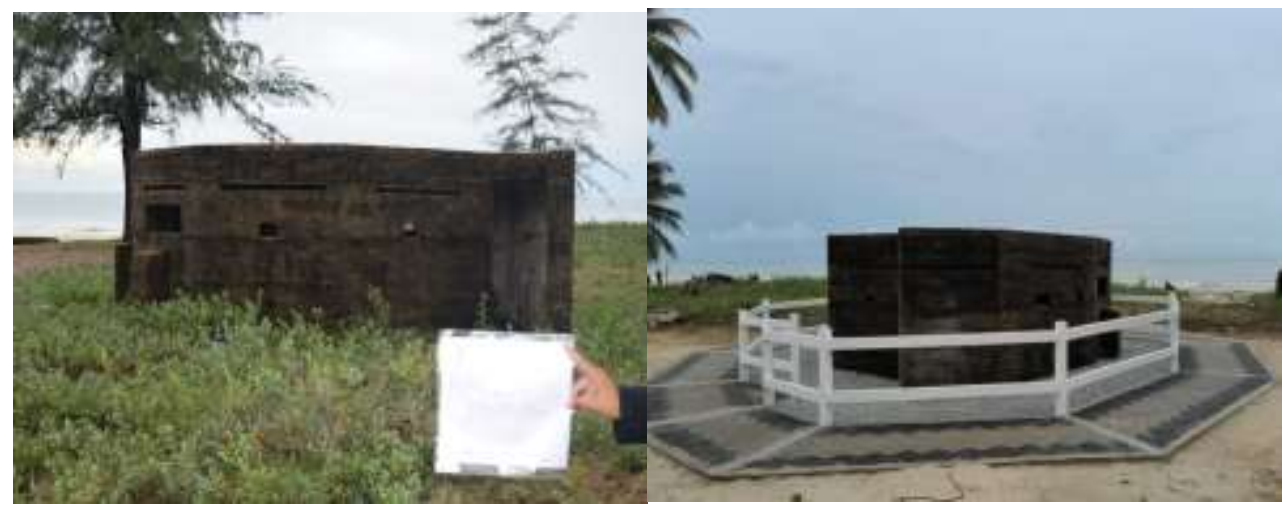

(A) Before

(B) After

Figure 8: The remaining British pillbox at Kg Ger, Bachok, Kelantan. Source: Field study and Nazli Ismail (2021).

The first British pillbox in Bachok is located at $\mathrm{Kg} \mathrm{Ger}$, on Melawi beach, and still shows the true structure of these monuments (Figure 8). It has strategic value for tourism, as there are chalets nearby and the scenery is attractive. In October 2021, this pillbox came under the preservation of the state government. The structure consists of nine walls and one doorway at the back for entry and exit. Each wall has a specific function that takes into account the angle of gunfire attack. The small holes in walls $A B, B C$, and $H I$ were designed for gunfire attack, whereas the wide holes in $\mathrm{CD}, \mathrm{DE}, \mathrm{EF}, \mathrm{FG}$, and $\mathrm{GH}$ were designed for observation of the positions and movements of enemy forces. The height of this pillbox is approximately $2,270 \mathrm{~mm}$. Two internal walls serve to strengthen the structure. The longest wall, $\mathrm{H}$ to I, measures $2,780 \mathrm{~mm}$, and the shortest wall, I to $\mathrm{J}$, measures $1,361 \mathrm{~mm}$. The angle of each wall is different: $50^{\circ}$ and $35^{\circ}$ for walls $A$ and $\mathrm{B}, 40^{\circ}$ and $20^{\circ}$ for $\mathrm{C}$ and $\mathrm{D}, 40^{\circ}$ and $15^{\circ}$ for $\mathrm{E}$ and $\mathrm{F}, 60^{\circ}$ and $15^{\circ}$ for $\mathrm{G}$ and $\mathrm{H}$, and $25^{\circ}$ for $\mathrm{I}$ (Figure 9). 


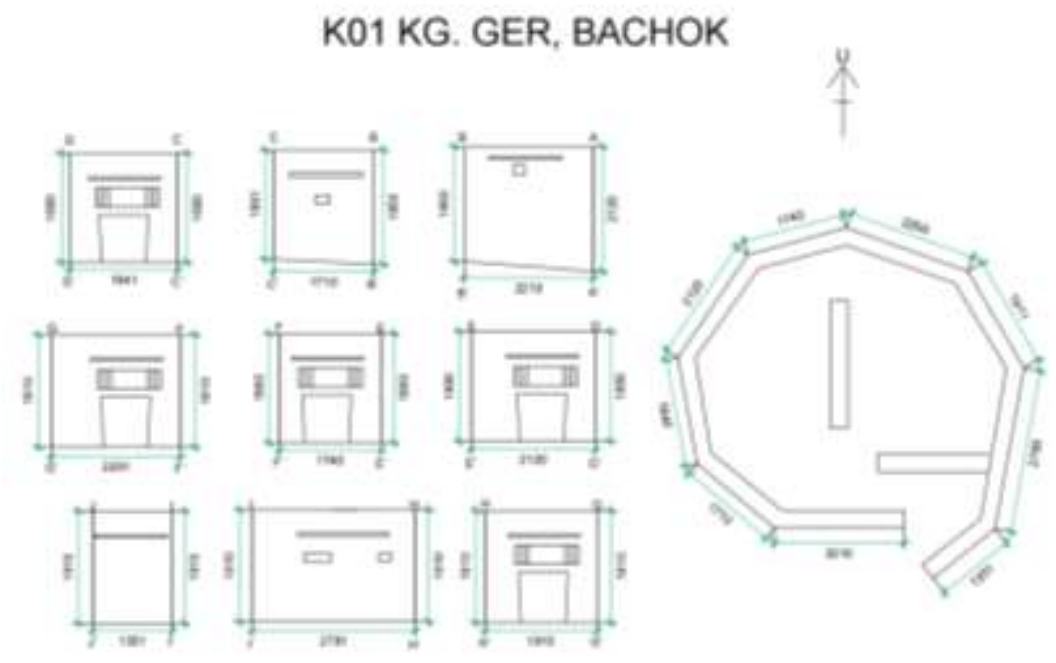

Figure 9: Measurements of the British pillbox at Kg Ger, Bachok, Kelantan. Source: Field study (2021).

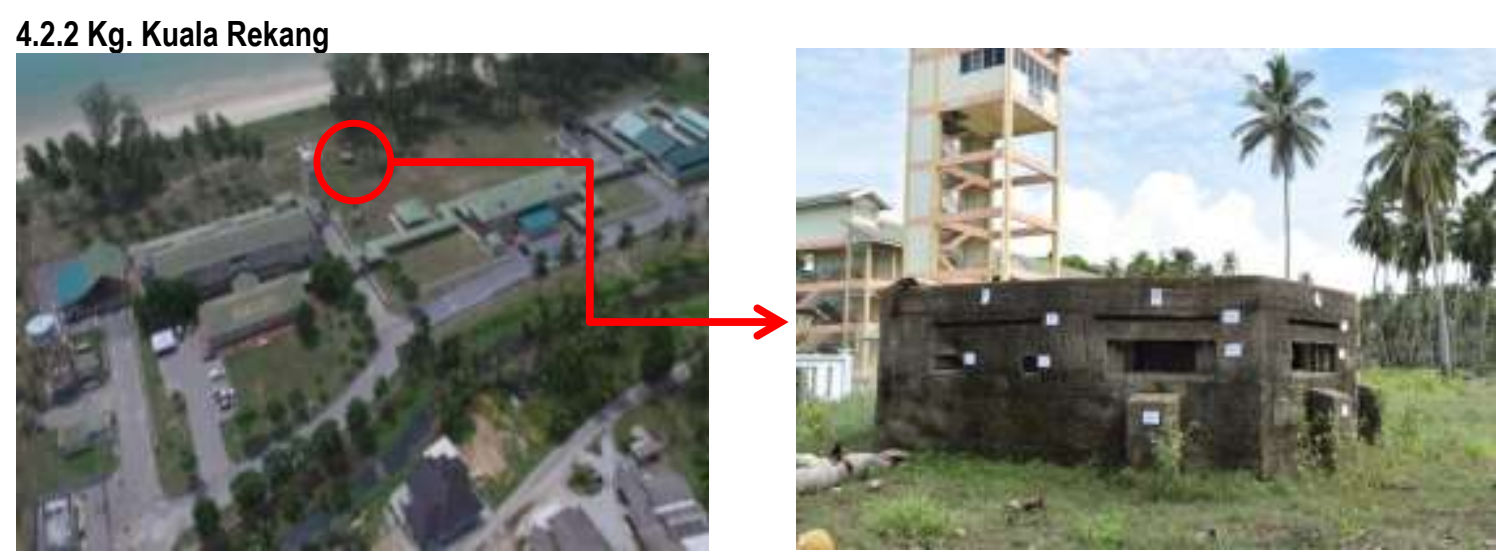

Figure 10: Location of the British pillbox at Kg Kuala Rekang, Bachok, Kelantan. Source: Field study and IOESUM (2012).

The next British pillbox is located $1 \mathrm{~km}$ from $\mathrm{Kg}$ Ger. After World War II, this area was unused until the construction of the Bachok Marine Station, Institute of Ocean and Earth Studies (IOES), University of Malaya (Figure 10). The pillbox lies outside the institution, very near the coast. Its structure is the same as the others under study here, but the measurements are somewhat different, with $\mathrm{HI}$ being the longest wall and IJ the shortest. The gunfire holes for $\mathrm{AB}, \mathrm{BC}, \mathrm{HI}$, and IJ are the same, as are the internal walls. The height, however, is different, at only $1,910 \mathrm{~mm}$ following erosion of the sand. The angles of walls $B$ to I are $40^{\circ}, 40^{\circ}, 60^{\circ}, 60^{\circ}, 15^{\circ}, 60^{\circ}, 15^{\circ}$, and $40^{\circ}$, respectively (Figure 11). Each wall is approximately $1 \mathrm{ft} \mathrm{thick.}$

\section{K02 KG. KUALA REKANG, BACHOK}
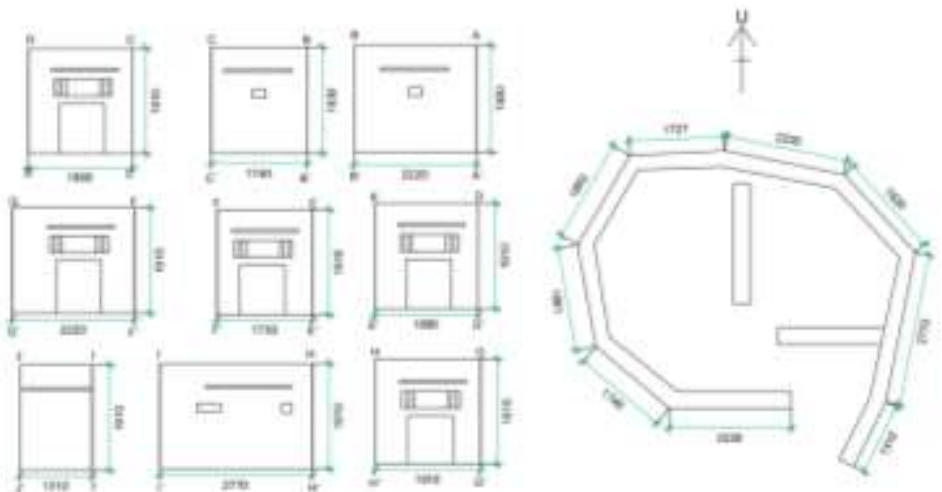

Figure 11: Measurements of the British pillbox at Kg Kuala Rekang, Bachok, Kelantan. Source: Field study. 


\subsubsection{Kg. Anak Rhu}

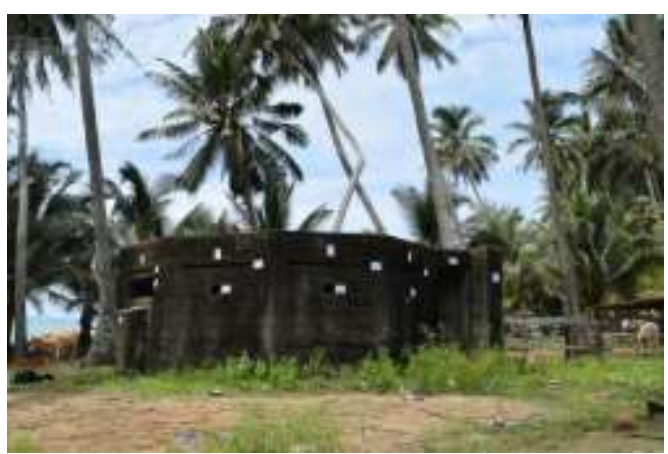

Figure 12: The structure and surrounding area of the pillbox at Kg Anak Rhu, Bachok, Kelantan Source: Field study.

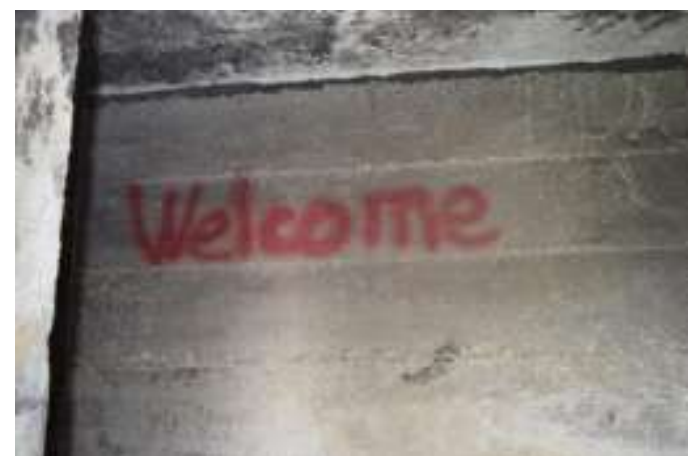

Figure 13: Traces of vandalism on the wall of the entrance of the pillbox at Kg. Anak Rhu, Bachok, Kelantan Source: Field study.

The third British pillbox is located in Kg Anak Rhu. After World War II, this area was populated by villagers whose houses and cowsheds surrounded the pillbox (Figure 12). As a result, it cannot be preserved, although it still has potential as a tourist attraction. The structure of this pillbox is different in terms of gunfire holes. There is a gun hole on wall $\mathrm{HI}$ only, and no holes on walls $A B, B C, C D$, or IJ. The structure of the pillbox remains sound, with only minor cracks and slight traces of vandalism (Figure 13). The angles of walls B to I are $40^{\circ}, 40^{\circ}$, $20^{\circ}, 35^{\circ}, 35^{\circ}, 40^{\circ}, 60^{\circ}$, and $10^{\circ}$, respectively (Figure 14). Each wall is approximately $1 \mathrm{ft} \mathrm{thick.}$

\section{K03 KG ANAK RHU}
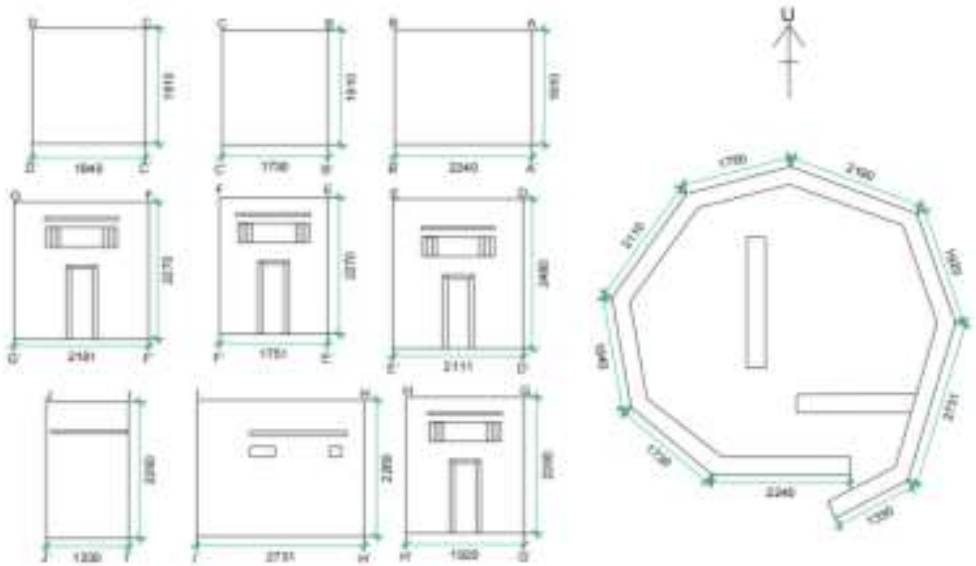

Figure 14: Measurements of the British pillbox at Kg Anak Rhu, Bachok, Kelantan. Source: Field study. 


\subsubsection{Kg. Pantai Baru}

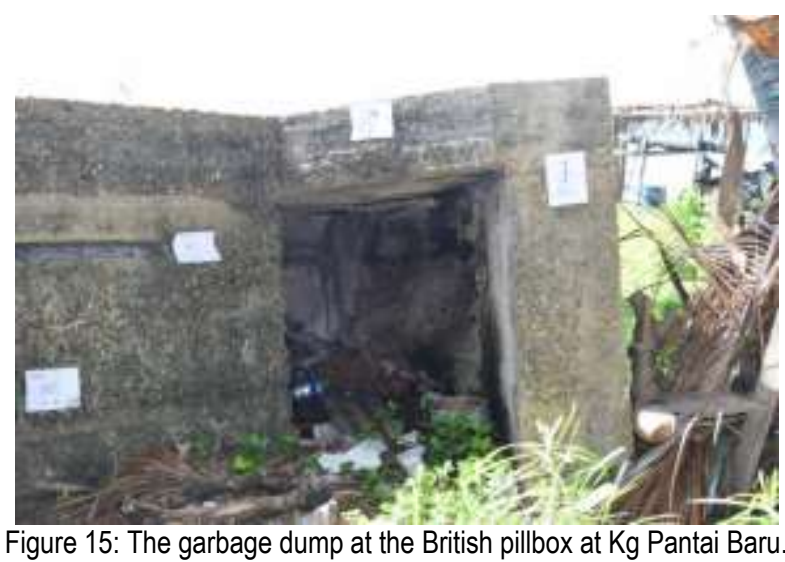

Source: Field study.

The fourth British pillbox is located in $\mathrm{Kg}$ Pantai Baru. As with the pillbox in $\mathrm{Kg}$ Anak Rhu, villagers, mainly fishermen, live nearby. This pillbox is surrounded by bushes and is used by the fisherman for equipment storage and as a garbage dump (Figure 15). It has clearly deteriorated because of its dirty surroundings, and it has also become embedded in the sand, to the extent that only a quarter of it is visible. However, the structure of the pillbox remains clear, especially the internal walls, which are the same as those of the pillboxes discussed above. The angles of walls $\mathrm{B}$ to I are $40^{\circ}, 30^{\circ}, 25^{\circ}, 60^{\circ}, 60^{\circ}, 60^{\circ}, 20^{\circ}$, and $40^{\circ}$, respectively (Figure 16). Each wall is approximately $1 \mathrm{ft}$ thick.

\section{K04 KG PANTAI BARU}

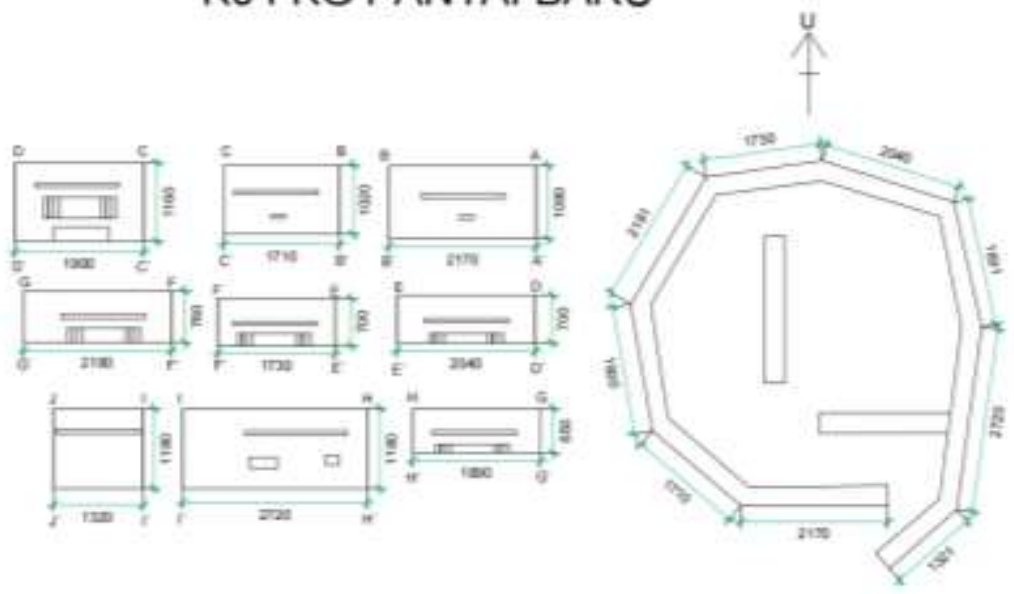

Figure 16: Measurements of the British pillbox at Kg Pantai Baru, Bachok, Kelantan. Source: Field study.

\subsubsection{Kg. Pantai Chap}

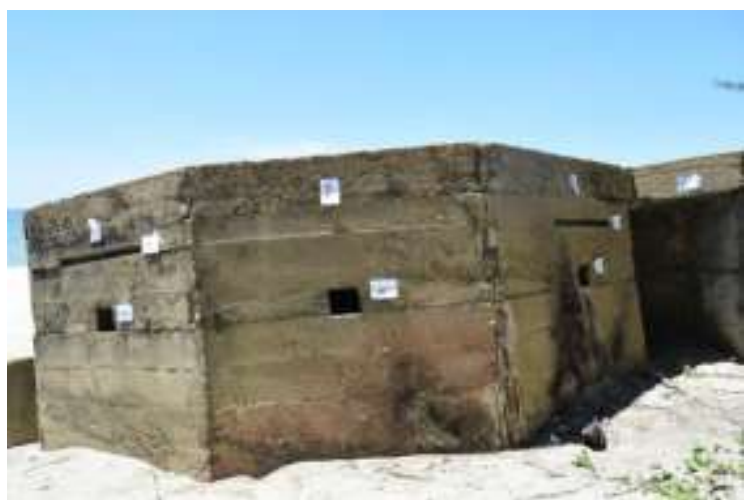

Figure 17: The structure of the British pillbox at Kg Pantai Chap, Bachok, Kelantan. Source: Field study. 
The fifth British pillbox in Bachok is located near chalets and a village populated by fishermen, and it, too, has become a garbage dump. Its condition is nevertheless good, with only minor damage, and the structure remains clearly visible (Figure 17). However, this pillbox, too, has become a garbage dump. The strategic potential for attracting tourism is clear but has not been acted on; it seems that the site's heritage value has yet to be recognized by society. The angles of walls $B$ to I are $40^{\circ}, 40^{\circ}, 40^{\circ}, 60^{\circ}, 60^{\circ}, 60^{\circ}, 20^{\circ}$, and $40^{\circ}$, respectively (Figure 18). Each wall is approximately $1 \mathrm{ft}$ thick.

\section{K05 KG PANTAI CHAP}
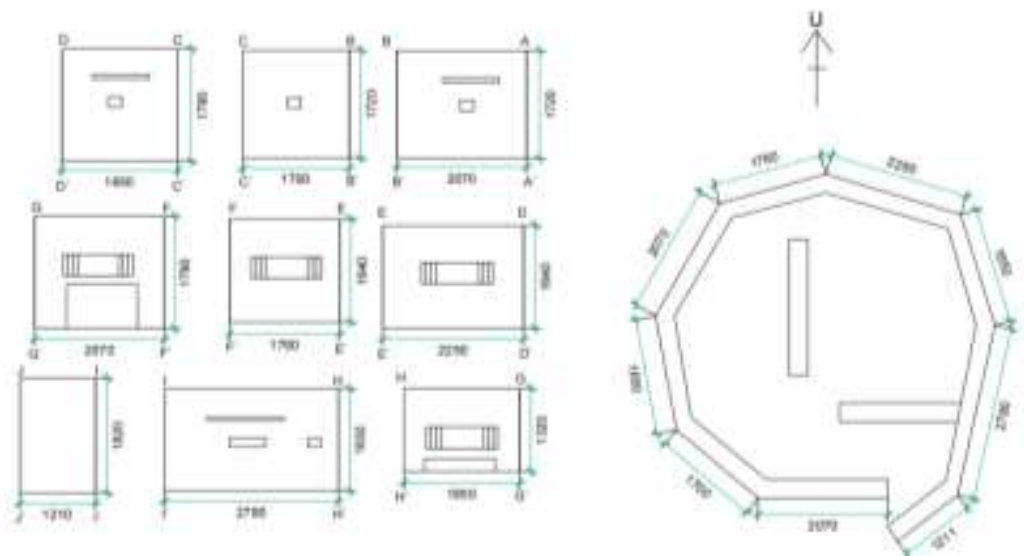

Figure 18: Measurements of the British pillbox at Kg Pantai Chap, Bachok, Kelantan. Source: Field study.

\subsubsection{Kg. Pantai Tok Abah}

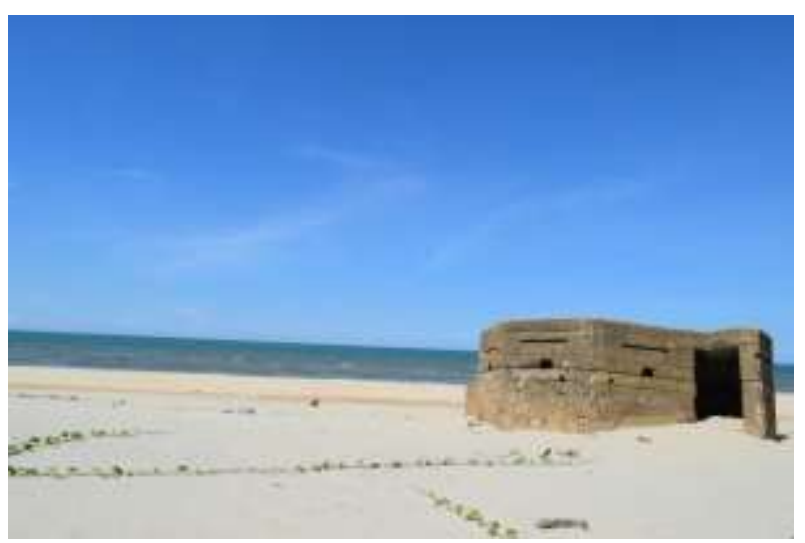

Figure 19: View of the British pillbox at Kg Pantai Tok Abah, Bachok, Kelantan. Source: Field study.

The last British pillbox in Bachok that can be measured is located near the Tok Abah chalets. It remains in good condition, with only minor damage, and the structure is visible (Figure 19). The strategic nature of the location has attracted some interest from Japanese tourists. According to the owner of the chalets, in the past year five tourists from Japan have come to the pillbox to make live recordings; with increasing numbers of visitors, this is a positive economic development for the area. The tourists often have questions about the pillbox, but the chalet owner lacks the knowledge to answer them. He is keen for local parties to take the opportunity to attract more heritage monument tourism to this fascinating and peaceful area. However, the heritage value of the site has not yet been recognized by society. The angles of walls $\mathrm{B}$ to $\mathrm{I}$ are $40^{\circ}, 40^{\circ}, 40^{\circ}, 60^{\circ}, 60^{\circ}, 60^{\circ}, 20^{\circ}$, and $40^{\circ}$, respectively (Figure 20). Each wall is approximately $1 \mathrm{ft}$ thick. 


\section{K06 PANTAI TOK ABAH}

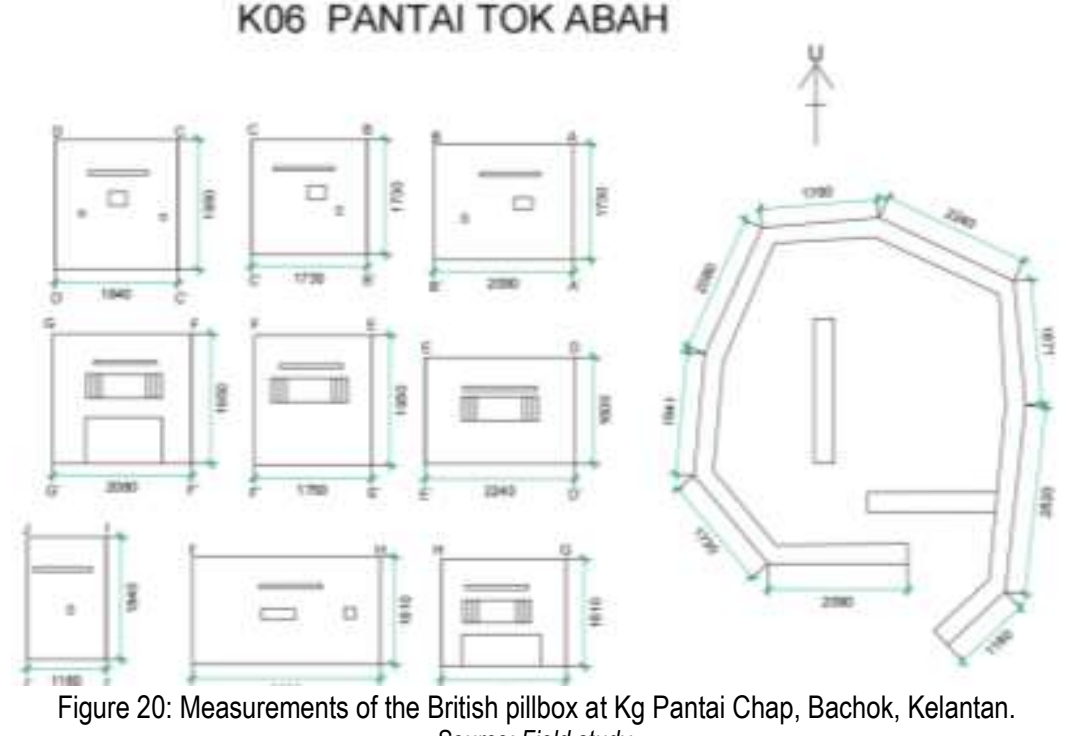

Source: Field study.

\subsection{Analysis of Questionnaire Responses}

This questionnaire was administered to 100 residents of Bachok (19 male and 81 female respondents). It consisted of two sections: section A for demographic information (gender, age, and profession), and section B for items measuring community awareness of the pillboxes in Bachok, Kelantan. The responses to section B are summarized in Table 2.

\subsubsection{Awareness of British Pillboxes in Bachok, Kelantan as Heritage Monuments}

Table 2: Awareness of the British pillboxes in Bachok, Kelantan as heritage monuments $(n=100)$.

\begin{tabular}{|c|c|c|c|c|c|c|c|}
\hline \multicolumn{2}{|c|}{ Participant Gender (\%) } & \multirow[b]{2}{*}{ Construct } & \multicolumn{5}{|c|}{ Participant Responses (\%) } \\
\hline Male & Female & & 1 & 2 & 3 & 4 & 5 \\
\hline 19 & 81 & The British pillboxes are heritage monuments. & 0 & 0 & 4 & 25.7 & 70.3 \\
\hline 19 & 81 & The pillboxes in Bachok, Kelantan have historical value. & 0 & 0 & 5 & 21.8 & 73.2 \\
\hline 19 & 81 & $\begin{array}{l}\text { The pillboxes in Bachok, Kelantan can be an object of } \\
\text { heritage tourism. }\end{array}$ & 0 & 0 & 8.9 & 22.8 & 68.3 \\
\hline 19 & 81 & $\begin{array}{l}\text { The pillboxes are capable of generating income through } \\
\text { heritage tourism. }\end{array}$ & 0 & 1 & 12.9 & 33.7 & 52.4 \\
\hline 19 & 81 & Has a high historical heritage value. & 0 & 2 & 6.9 & 25.7 & 65.4 \\
\hline 19 & 81 & Can be transformed into a tourist destination. & 0 & 0 & 5 & 25.7 & 69.3 \\
\hline
\end{tabular}

Source: Field study.

Of the respondents, $70.3 \%$ strongly agreed with the statement that the British pillboxes are heritage monuments, and a further $25.7 \%$ agreed. Similarly, $73.4 \%$ strongly agreed that the pillboxes have historical value, while $21.8 \%$ agreed. Levels of agreement were lower, but still relatively strong, for the statements that the pillboxes can be objects of heritage tourism ( $68.3 \%$ strongly agree, $22.8 \%$ agree), that the pillboxes are capable of generating income through heritage tourism ( $52.4 \%$ strongly agree, $33.7 \%$ agree), that the pillboxes have high heritage value (65.4\% strongly agree, $25.7 \%$ agree), and that the pillboxes can be transformed into a tourist destination $(69.3 \%$ strongly agree, $25.7 \%$ agree). A small minority of respondents disagreed with or were unsure about each statement, which indicates that some people lack awareness of the pillboxes in Kelantan as heritage monuments.

\subsection{Conclusion}

In conclusion, the British pillboxes in Kelantan have significant value as historical monuments, as they were built by the British armed forces during World War II. As such, they must be preserved as a symbol of the success of Malaysia as an independent state. They can also have a positive impact on the fields of tourism and heritage education, contributing to greater awareness in society of the heritage monuments that exist in Malaysia, including but by no means limited to these pillboxes. Society's awareness of heritage monuments is an essential element in understanding and preventing a recurrence of colonialism, and heritage knowledge should therefore be fostered among the younger generations. One element of this is ensuring that young people continue to have the opportunity to learn about the pillboxes on the shores of Bachok both as structures and as monuments. Moreover, the pillboxes can contribute to the local economy in Kelantan, and to the economy of Malaysia more broadly, by enhancing the heritage tourism sector. 


\section{Acknowledgements}

This article is in recognition of the FRGS 2020 grant entitled Pencirian Struktur Binaan Kubu Peperangan British Di Negeri Kelantan Untuk Tujuan Konservasi (Ref: FRGS/1/2020/SS0/UMK/03/1 (KPT) and R/FRGS/A0200/01079A/002/2020/00898 (UMK)).

\section{Paper Contribution to Related Fields Of Study}

This paper of research was contributed to several factors in heritage fields. This research paper focus on monuments that own significant value and heritage value that should be preserved and conserved in many ways to remaining the importance arts of architecture and heritage cultures. This research also stated some idea for economic growth in country through heritage tourism.

\section{References}

AW Kebangsaan (2006). Akta Warisan Kebangsaan 2005. Retrived from https://gtwhi.com.my/wp-content/uploads/2020/12/Akta-Warisan-Kebangsaan-2005.pdf.

Dato` HL Wrigglesworth (2006). The Japanese Invasion of Kelantan in 1941:Perbadanan Muzium Negeri Kelantan.

Dato` Nik Mohamed Nik Mohd Salleh (1988). Peperangan Dunia Kedua Di Kelantan : Disember 1941: Perbadanan Muzium Negeri Kelantan.

Derkommander (2017). Peta Kelantan. Retrived from https://www.iconspng.com/image/39827/map-of-kelantan-malaysia.

DJ Dolasoh (2015). Kubu Lama Tarikan Pelancong. Harian Metro. http://www.google.com/amp/s/www.hmetro.com.my/node/83588/amp, last accessed 2021/7/18.

Nur Farhana Shuhaimi (2020). Konservasi Monumen: Pendokumentasian Kubu Peperangan British di Jalan Tok Hakim, Kota Bharu, Kelantan. Bachelor`s Degree Thesis in Heritage Studies. University Malaysia Kelantan, Kelantan, Malaysia (Unpublished).

Jeffrey Heys (2008). Malaysia During And After World War II. Rerived from https://factsanddetails.com/southeast-asia/Malaysia/sub54a/entry-3622.html.

Nik Mohamed B Nik Mohd. Salleh (1995). Warisan Kelantan : Perbadanan Muzium Negeri Kelantan.

Salleh Mohd Akib 2013 Kesan-kesan Tinggalan Perancangan Dunia Kedua 1941-1945 Di Kelantan: Perbadanan Muzium Negeri Kelantan.

Nur Athmar Hashim, Tengku Fauzan Tengku Anuar, Siti Aishah Muhammad, Suresh Narayanen, Mokhtar Saidin, Nawwal Abdul Kadir, Nur Farhana Shuhaimi, dan Adam

Mad Zain (2020), Analysis of the Causes of Destruction of Two British Pillboxes in Bachok, Kelantan.IOP Conf. Ser.: Earth Environ. Sci. 549012082.

Nazli Ismail (2021). Tarikan Pelancongan Baru: Kubu Peninggalan Penjajah Inggeris di Kg. Ger, Bachok. Retrived from https://www.facebook.com/oghebachok/.

Salleh Mohd Akib (2013). Kubu Kebal British:Perbadaan Muzium Negeri Kelantan. 